УДК 37.04:159.9]:[378.147.091:376-054.62]

Д. В. Фурт,

старший викладач

(Донецький національний університет економіки та торгівлі ім. М. Т. Барановського, м. Кривий Ріг) dariafurtegmail.com

ORCID: 0000-0003-2266-1611

\title{
ПСИХОЛОГІЧНІ ЧИННИКИ ФОРМУВАННЯ ТЕРМІНОЛОГІЧНОЇ КОМПЕТЕНТНОСТІ СТУДЕНТІВ-ІНОЗЕМЦІВ
}

\begin{abstract}
У статті проаналізовано психологічні чинники формування термінологічної компетентності студентів-іноземиів у процесі навчання украӥнської мови. Узагальнено погляди науковців на проблему та виокремлено особливості вивчення української мови іноземними студентами. Виокремлено основні компоненти вивчення украӥнської мови. Охарактеризовано поняття "мотиваџія" та "мотив", розглянуто відмінності між досліджуваними поняттяями. Наведені характеристики діяльності студентів-іноземиів та обгрунтовано вплив психологічних чинників на формування термінологічної компетентності іноземних студентів.
\end{abstract}

Ключові слова: студенти-іноземиі, психологічні чинники, термінологічна компетентність, українська мова як іноземна, українська термінологія, навчальна діяльність.

Постановка проблеми. Засвоєння лексики під час вивчення іноземної мови $є$ одним з найскладніших аспектів практики навчання іноземної мови. Невеликий словниковий запас змушує студентів відчувати невпевненість та викликає небажання говорити іноземною мовою, тому розширення словникового запасу студентів-іноземців $є$ однією 3 основних завдань на заняттях української мови. Відомо, що якісно сформовані лексичні навички - головна умова успішного спілкування мовою, а порушення лексикосемантичної норми призводить до різних смислових помилок, які роблять мову комунікативнонедосконалою або зовсім незрозумілою.

Засвоєння термінологічної лексики іноземними студентами дозволяє розширити процеси обміну інформацією, підвищити якість сприйняття навчального матеріалу, адекватно використовувати поняття.

Вивчення української мови та термінології є завданням досить складним для студентів-іноземців. Для створення методики навчання української термінології студентів-іноземців, необхідно враховувати психологічні чинники.

Метою статті $\epsilon$ визначення психологічних чинників, які сприяють формуванню термінологічної компетентності студентів-іноземців.

Виклад основного матеріалу. Іноземна мова характеризуеться низкою ознак. Так, у своїй роботі I. Зимня виокремлює певні відмінності між іноземною мовою та рідною. Першою відмінністю $є$ напрям шляху оволодіння. Рідній мові характерний шлях "знизу-вгору", тоді як для іноземної мови - "зверху вниз". Рідна мова засвоюється несвідомо, а іноземна - починаючи з усвідомлення [1].

Суттєвою відмінною особливістю оволодіння іноземною мовою є одностороннє "включення" в комунікативну, а не в предметно-комунікативну діяльність. Студенти часто спілкуються українською мовою тільки під час занять і не використовують ії у своїй безпосередній предметній діяльності. Це призводить до того, що, наприклад, слово іншомовного походження живе в мовній свідомості студента тільки у своїй абстрактно-логічній, понятійній сфері, що може слугувати однією з причин слабкості збереження іншомовного терміна в пам'яті, труднощів його актуалізації [2].

Оволодіння українською мовою найчастіше визначається як задоволення навчально-пізнавальної потреби, або потреби усвідомлення форми вираження власної думки. Спостереження над мовою $\epsilon$ спостереженнями над мисленням і примушує людину зупинятися на потоці своєї промови, а, отже, i мислення, змушуючи членувати його на частини, вдумуватися у співвідношення цих частин, порівнювати ї одне з одним і поглиблювати цим їх розуміння. Необхідно також звернути увагу на характеристику мови як засобів задоволення комунікативної потреби вираження думок, почуттів, волі. Рідна - природна форма усвідомлення існування та позначення емоційно-вольової сфери людини. Будьяка інша мова, співіснуючи, не підміняє і тим більше не витісняє рідну мову в цій функції. Свідченням цього є той факт, що саме інтимне, мимовільне, особистісно-значуще, люди, які володіють кількома мовами, висловлюють тільки рідною мовою.

У XIX столітті психологія внесла багато нового в методику навчання іноземних мов. Для прикладу можна згадати погляди В. Вундта на психологію мови і почуттів. Пізніше у психології був накопичений великий теоретичний матеріал, встановлено закономірності, що проявляють себе як у засвоєнні й оволодінні мовою, так і у вивченні будь-якого предмета. Г. Ведель виокремлює такі закономірності: теорія єдності свідомості та діяльності; теорія поетапного формування розумових процесів; теорія установки; концепція відкритого та прихованого способу навчання; теорія ступеня інтенсивності стану 
збудження учнів в процесі навчання; концепція внутрішнього мовлення та латентної артикуляції, основного механізму як словесного, так й образного мислення; теорія латентної вербалізації [3].

Пошук нових шляхів інтенсифікації та підвищення якості навчання мови як іноземної не може не враховувати той факт, що в період навчання студентів-іноземців у країні, мова якої вивчається, прогрес у вивченні мови в багато разів перевищує досягнення за аналогічний період вивчення мови на батьківщині студента-іноземця. Відомо також, що мова в мовному середовищі засвоюється дещо іншим шляхом, ніж поза ним: у рідномовному середовищі переважає засвоєння мови через дійсність, тоді як в іншомовному, навпаки: дійсність засвоюється через мову [4: 54].

I. Назарова наголошує на безперечних перевагах мовного оточення, що характеризується спонтанним ситуативним спілкуванням із носіями мови. Така комунікація закріплює навички, отримані студентами на заняттях. Має місце так званий ефект "занурення" в мовне та культурне середовище, що характеризується певною стихійністю та ріднить його з процесом оволодіння дитиною рідною мовою [5: 55].

Лінгводидактичне середовище - це методична даність, це спеціальне середовище, "методична система, яка створена задля навчання на базі об'єктивно існуючих реалій" [4: 118], та яка цілеспрямовано сприяє формуванню вторинної мовної особистості.

Т. Ауербах зазначає, що, на відміну від інших навчальних предметів, іноземна мова $є$ одночасно i метою і засобом навчання [6: 21].

У методиці викладання іноземної мови науковці виокремлюють три основні компоненти. Лінгвістичний - включає мовний, мовленнєвий і лінгвокраїнознавчий матеріал. Психологічний - основа формування навичок та умінь використання мови, яку вивчають, із підвидами мовних навичок (вимови, граматичних, лексичних, орфографічних), а також мовленнєвих умінь, пов'язаних із розумінням мовлення на слух, говорінням, читанням і письмом [7: 9].

Психологічні основи сприяють правильності застосування різних методів навчання на певному етапі, певної вікової категорії, певного фахового спрямування. Це дає оптимальні результати засвоєння навчального мовленнєвого матеріалу і сприяє його перетворенню на мовленнєву модель у практичній діяльності.

Л. Селіверстова згадує про чинники, що визначають процес навчання, як-то: цільова настанова, вікові особливості слухачів (студентів), їхня попередня підготовка, об'єктивні умови викладання тощо, які опираються на психологічну основу [7; 9]. Автор також наголошує на тому, що навчання української мови як іноземної вимагає водночас практичного оволодіння законами мови й мовлення в короткий термін, що й пояснює важливе значення лінгвістичної та психологічної основ навчання. Науковці розглядають діалектичну єдність мови і мислення як єдність форми і змісту. Дійсно, наші думки оформлюються через мову. Навчати мови - це не означає навчати іншого способу мислення, а, радше, навчити викладати свою думку чужою мовою так, щоб був зрозумілий зміст думки. Зв'язок української мови, яку вивчає студент як іноземну, і мислення, сформованого рідною мовою, безперечно, функціонує так, що новий спосіб мислення формується засобом української мови через набуття певного життєвого або фахового, теоретичного або практичного досвіду сучасної реальності. Отже, не можна навчити іншомовного мислення, а можна розвивати мислення майбутнього фахівця українською мовою. Перед викладачем постає завдання навчити іноземця користуватись українською мовою у процесі формування його загальнолюдських і фахових знань[7; 9].

I. Зимня узагальнює психологічні характеристики навчальної діяльності та зазначає п’ять ії основних характеристик порівняно з навчанням:

1) спеціальну спрямованість на оволодіння навчальним матеріалом та рішення навчальних завдань;

2) освоєння загальних способів дій та наукових понять;

3) наявність загальних способів дії, які випереджають розв'язання завдань (І. Ільясов);

4) зміна самого суб’єкта в навчальній діяльності (Д. Ельконін);

5) активність, яка проявляється в зміні психічних властивостей і поведінки того, хто навчається (залежно від результатів власних дій) (І. Лінгарт).

Навчальна діяльність також визначається як один із видів інтелектуальної діяльності, яка має структурні компоненти: мотивацію; навчальні завдання в певних ситуаціях та різній формі завдань; навчальні дії; контроль, що переходить в самоконтроль; оцінка, що переходить у самооцінку [8].

На думку О. Леонтьєва мотиви, диференціюють діяльності, утворюють психологічну відмінність між ними, діяльності класифікуються, упорядковуються, навіть відокремлюються одна від одної саме за ознакою мотиву [9].

Мотиви діяльності мають двояку функцію. Вона полягає в тому, що мотиви - це те об'єктивне, що спонукає та спрямовує на себе діяльність. У цьому й полягає спонукальна функція мотивів. Інша функція полягає в тому, що цілі, на які спрямовуються дії, і зміст цих дій набувають особливого значення для самого суб'єкта діяльності. Таку функцію О. Леонтьєв називає "функцією смислоутворення". Під 
"смислоутворенням" він розуміє надання окремим діям, окремим утриманням цих дій особистісного сенсу [9].

Залежно від індивідуальних психологічних особливостей та якостей особистості в іноземних студентів формується певний спосіб виконання діяльності в процесі пізнання, шлях пізнання світу, або когнітивний стиль. Дослідники виокремлюють різну кількість когнітивних стилів. Вони співвідносяться 3 психологічними характеристиками типу особистості та якостями людини. Слідом за І. Колесниковою й О. Долгін [10], ми вважаємо, що основними когнітивними стилями, які іноземні студенти використовують під час навчання української мови, є такі: польова незалежність / залежність; домінувальна роль однієї з півкуль головного мозку; толерантність; рефлективність або імпульсивність; візуальний або слуховий стилі.

Кожен іноземний студент під час вивчення української мови використовує певний набір когнітивних стилів. Найбільш успішною виявляється діяльність тих, хто свідомо вибирає й ефективно використовує різні когнітивні стилі.

Когнітивні стилі, характерні для того чи іншого іноземного студента, визначають його навчальний стиль, або стиль його діяльності.

У психології "діяльність" розглядається як єдність мотиваційного, цільового та виконавчого аспектів, хоч iї основою - початком - є мотиваційно-спонукальна сфера, яка визначається діями людини. Тобто, ті почуття та емоції, які переживає студент під час засвоєння нової термінології, впливають на процес прийому та опрацювання інформації, надаючи усій його діяльності певний емоційний тон. Саме відчуття, які переживає студент, виконують як сигнальну функцію, інформуючи про важливість інформації для певного студента, так і регулятивну функцію, управляючи подальшим перебігом сприйняття. Оскільки сформоване позитивне ставлення до вивчення нових термінологічних одиниць здатне значно покращити якість засвоєння, необхідно залучати до загальної структури етапів засвоєння й етап створення позитивного ставлення до матеріалу, який сприймається.

Для студентів-іноземців українська мова є інструментом отримання вищої та середньої професійної освіти, що підвищує мотивацію до вивчення мови. Цей факт також свідчить про важливість тренування рецептивних та репродуктивних видів мови, обліку особливої ролі читання та вміння слухати лекції у пізнавальній діяльності студентів, оскільки перед викладачем української мови як іноземної стоїть завдання пристосування навчальної програми до індивідуальних особливостей та потреб студентів.

Психолінгвістичне знання також орієнтує викладача на облік вікового чинника студентів під час організації навчального процесу задля підвищення мотивації до вивчення мови. Від дорослої людини оволодіння українською мовою вимагає набагато більше зусиль, ніж від дитини, оскільки психічні процеси дорослого вже стабільні, процес розвитку стає не таким активним, з чого випливає, що у дорослої людини йде більше часу та сил на вивчення іноземної мови. Такий процес вимагає гнучкості мислення, запам'ятовування численних правил та вокабулярних одиниць, що необхідно для формування навичок правильного використання вивченого матеріалу задля висловлення своїх думок та розуміння чужих висловлювань.

У процесі оволодіння другою мовою в людини відбувається формування вторинної мовної особистості - здатності людини до мовних актів в умовах автентичного спілкування з представниками культури, що вивчається [11: 52]. У виборі стратегій навчання іноземних студентів української мови необхідно враховувати той факт, що процес навчання дорослих повинен відповідати не тільки когнітивним і комунікативним очікуванням, а й особистісним. У навчанні підтримується індивідуальний підхід, що випливає з особистих інтересівтаі життєвих потреб студентів.

На етапі навчання студентів іноземців в економічних вищих школах України питання адаптації до українських реалій не постає гостро, адже подолання адаптаційного періоду відбувається на етапі підготовчих курсів, однак адаптація як процес пристосування до нового колективу та нових правил ВНЗ все ж має місце.

Висновки. Під час вивчення української мови у ВНЗ України студенти-іноземці мають проблеми пов'язані з засвоєнням нової термінологічної лексики: мотивація студента, його активність, опрацювання нової термінології, "включення" в предметно-комунікативну діяльність, вікові особливості студентів, їхн попередня підготовка, об’єктивні умови викладання тощо. Для подолання проблем викладачеві необхідно дібрати певну стратегію викладання, узявши до уваги вік студентів, країни, де вони народилися, врахувавши індивідуальні особливості та потреби студентів та створивши таке мовне середовище, у якому студенти мали б змогу максимально наблизитися до реальних ситуацій, використати свій потенціал, знання та вміння.

\section{СПИСОК ВИКОРИСТАНИХ ДЖЕРЕЛ ТА ЛІТЕРАТУРИ}

1. Зимняя И. А. Психологические аспекты обучения говорению на иностранном языке / И. А. Зимняя. - М., 1985.

2. Зимняя И. А. Психология обучения иностранному языку в школе / И. А. Зимняя. - М. : Просвещение, 1991. $53 \mathrm{c}$. 
3. Ведель Г. Е. Из истории методов преподавания иностранных языков / Г. Е. Ведель. - Воронеж, Изд-во Воронеж, ун-та, 1979. - $56 \mathrm{c.}$

4. Орехова И. А. Языковая среда : попытка типологии / И. А. Орехова. - Гос. ин-т рус. яз. им. А. С. Пушкина, Информ.-учеб. центр. - М. : Гос. ин-т рус. яз., 2003. - 193 с.

5. Назарова И. В. Из опыта обучения РКИ в условиях отсутствия языковой среды / И. В. Назарова // Проблемы преподавания филологических дисциплин иностранным учащимся: мат. междунар. научно-метод. конференции 28-29 января 2010 года. - Воронеж, 2010. - С. 55-60.

6. Ауэрбах Т. Д. Зачем и как изучать иностранный язик / Т. Д. Ауэрбах. - М. : Знание, 1961. -21 с.

7. Селіверстова Л. Лінгвістична та психологічна основа навчання української мови як іноземної / Л. Селіверстова / Теорія і практика викладення української як іноземної. - 2007 р. - Вип. 2. - С. 8-13.

8. Зимняя И. А. Педагогическая психология : [учебник для вузов]. - 2-е изд. доп., испр. и перераб / И. А. Зимняя. - М. : Логос, 2005. - 384 с.

9. Леонтьев А. Н. Лекции по общей психологи / А. Н. Леонтьев - М. : Смысл; КДУ, 2005. - 511 с.

10. Колесникова И. Л. Англо-русский терминологический справочник по методике преподавания иностранных языков / И. Л. Колесникова, О. А. Долгина - СПб. : Изд-во "Русско-Балтийский информационный центр "БЛИЦ", "Cambridge University Press", 2001. - 224 с.

11. Белянин В. П. Введение в психолингвистику / В. П. Белянин. - М. : ЧеРо, 1999. - 128 с.

\section{REFERENCES (TRANSLATED \& TRANSLITERATED)}

1. Zimniaia I. A. Psihologicheskiie aspekty obucheniia govoreniiu na inostrannom yazyke [Psychological Aspects of Learning How to Speak in a Foreign Language] / I. A. Zimniaia. - M., 1985.

2. Zimniaia I. A. Psikhologiia obucheniia inostrannomu yazyku v shkole [Psychology of Teaching Foreign Language at School] / I. A. Zimniaia. - M. : Prosvescheniie, 1991. - $53 \mathrm{~s}$.

3. Vedel G. E. Iz istorii metodov prepodavaniia inostrannykh yazykov [From the History of Methods of Foreign Languages Teaching] / G. E. Vedel. - Voronezh, Izd-vo Voronezh. un-ta, 1979. - 56 s.

4. Orekhova I. A. Yazykovaia sreda : popytka tipologii [Language Environment : Typology Attempt] / I. A. Orekhova. - Gos. in-t rus. yaz. im. A. S. Pushkina, Inform.-ucheb. tsentr. - M. : Gos. in-t rus. yaz., 2003. - 193 s.

5. Nazarova I. V. Iz opyta obucheniia RKI v usloviiakh otsutstviia yazykovoi sredy [From the Experience of Teaching Russian as a Foreign Language in the Absence of Language Environment]/ I. V. Nazarova // Problemy prepodavaniia filologicheskikh distsiplin inostrannym uchaschimsia : [mat. mezhdunar. nauchno-metod. konferentsii 28-29 yanvaria 2010 goda]. - Voronezh, 2010. - S. 55-60.

6. Auerbakh T. D. Zachem i kak izuchat' inostrannyi yazyk [Why and How Should You Study Foreign Language]/ T. D. Auerbakh. - M. : Znaniie, 1961. - $21 \mathrm{s.}$

7. Seliverstova L. Linhvistychna ta psykholohichna osnova navchannia ukrains'koi movy yak inozemnoi [Linguistic and Psychological Basis for Teaching Ukrainian Language] / L. Seliverstova // Teoriia i praktyka vykladennia ukrainskoi yak inozemnoi [Theory and Practice of Teaching Ukrainian as Foreign Language]. - 2007. - Vyp. 2. S. $8-13$

8. Zimniaia I. A. Pedagogicheskaia psikhologiia [Pedagogical Psychology] : [uchebnik dlia vuzov] / I. A. Zimniaia. 2-e izd. dop., ispr. i pererab. - M. : Logos, $2005-384$ s.

9. Leontiev A. N. Lektsii po obschei psikhologii [Lectures on General Psychology] / A. N. Leontiev. - M. : Smysl; KDU, 2005. $-511 \mathrm{~s}$.

10. Kolesnikova I. L. Anglo-russkii terminologicheskii spravochnik po metodike prepodavaniia inostrannykh yazykov [English-Russian Terminology Reference Book on Teaching Methods for Foreign Languages ] / I. L. Kolesnikova, O. A. Dolgina - SPb. : Izd-vo "Russko-Baltiiskii informatsionnyi tsentr "BLITs", "Cambridge University Press", 2001. $-224 \mathrm{~s}$.

11. Belianin V. P. Vvedeniie v psikholingvistiku [Introduction into Psycholinguistics] / V. P. Belianin. - M. : CheRo, 1999. $-128 \mathrm{~s}$.

\section{Фурт Д. В. Факторы формирования терминологической компетентности студентов-иностранцев.}

В статье представлен обзор психологических факторов формирования терминологической компетентности студентов-иностранцев в процессе обучения украинскому языку. Обобщенные взгляды

ученых на проблему и выделены особенности изучения иностранного языка студентами. Выделены основные компоненты изучения украинского языка. Охарактеризованы понятия "мотивация" и "мотив", рассмотрены различия между исследуемыми понятиями. Приведенные характеристики деятельности

студентов-иностранцев и обосновано влияние психологических факторов на формирование терминологической компетентности иностранных студентов.

Ключевые слова: студенты-иностранцы, психологические факторы, терминологическая компетентность, украинский язык как иностранный, украинская терминология, учебная деятельность.

\section{Furt D. V. Psychological Factors in the Foreign Students' Terminological Competence Formation.}

The research deals with charity issues in teaching Ukrainian to foreign students. The article containing information on clarifying the notions "motive" and "motivation", and includes the information about their 
differences. The scientific methods of analysis, synthesis, description and comparison have been used in order to single out the psychological factors in the foreign students' terminological competence formation during the Ukrainian language studying. The scientists' views on the issue are considered and the features of foreign language studying are singled out. The characteristics of foreign students' activity and the influence of psychological factors on the terminological competence formation were analyzed. As a result it is proved that psychological factors are very important in terminological competence formation. Learning Ukrainian foreign students face problems associated with learning new terminology vocabulary: student motivation, his activity, conversion of a new terminology, and "inclusion" in the subject-communicative activity, students' age, their previous training. To overcome the problems the teacher should develop a strategy for teaching, taking into consideration students' age, the country where they were born, students' individual characteristics and needs. The teacher should also create a language environment in which students would be able to be close to real situations, to use their potential, knowledge and skills.

Key words: foreign students, psychological factors, terminological competence, Ukrainian as a foreign language, Ukrainian terminology, training activities. 